\title{
Glacier changes in the Koshi River basin, central Himalaya, from 1976 to 2009, derived from remote-sensing imagery
}

\author{
SHANGGUAN Donghui, ${ }^{1,3}$ LIU Shiyin, ${ }^{1}$ DING Yongjian, ${ }^{1}$ WU Lizong, ${ }^{1}$ DENG Wei, ${ }^{2}$ \\ GUO Wanqin, ${ }^{1}$ WANG Yuan, ${ }^{1} \mathrm{XU}$ Junli, ${ }^{1}$ YAO Xiaojun, ${ }^{1}$ GUO Zhilong, ${ }^{1}$ \\ ZHU Wanwan ${ }^{1}$
}

\author{
${ }^{1}$ State Key Laboratory of Cryospheric Science, Cold and Arid Regions Environmental and Engineering Research Institute, \\ Chinese Academy of Sciences, Lanzhou, China \\ E-mail: dhguan@Izb.ac.cn \\ ${ }^{2}$ Institute of Mountain Hazards and Environment, Chinese Academy of Sciences, Chengdu, China \\ ${ }^{3}$ Department of Geography, University of Zürich, Zürich, Switzerland
}

\begin{abstract}
We use remote-sensing and GIS technologies to monitor glacier changes in the Koshi River basin, central Himalaya. The results indicate that in 2009 there were 2061 glaciers in this region, with a total area of $3225 \pm 90.3 \mathrm{~km}^{2}$. This glacier population is divided into 1290 glaciers, with a total area of $1961 \pm 54.9 \mathrm{~km}^{2}$, on the north side of the Himalaya (NSH), and 771 glaciers, with a total area of $1264 \pm 35.4 \mathrm{~km}^{2}$, on the south side of the Himalaya (SSH). From 1976 to 2009, glacier area in the basin decreased by about $19 \pm 5.6 \%\left(0.59 \pm 0.17 \% \mathrm{a}^{-1}\right)$. Glacier reduction was slightly faster on $\mathrm{SSH}$ $(20.3 \pm 5.6 \%)$ than on NSH $(18.8 \pm 5.6 \%)$. The maximum contribution to glacier area loss came from glaciers within the $1-5 \mathrm{~km}^{2}$ area interval, which accounted for $32 \%$ of total area loss between 1976 and 2009. The number of glaciers in the Koshi River catchment decreased by 145 between 1976 and 2009. Glacier area on SSH decreased at a rate of $6.2 \pm 3.2 \%\left(0.68 \pm 0.36 \% \mathrm{a}^{-1}\right)$, faster than on $\mathrm{NSH}$, where the rate was $2.5 \pm 3.2 \%\left(0.27 \pm 0.36 \% \mathrm{a}^{-1}\right)$ during $2000-09$. Based on records from Tingri weather station, we infer that temperature increase and precipitation decrease were the main causes of glacier thinning and retreat during the 1976-2000 period. Glacier retreat during the 2000-09 period appears to be controlled by temperature increase, since precipitation increase over this period did not offset ice losses to surface melting.
\end{abstract}

KEYWORDS: glacier fluctuations, glacier mapping, remote sensing

\section{INTRODUCTION}

Glaciers are an important indicator of global climate change, and additionally have important roles in various feedbacks and amplifications associated with climate change (Cheng, 1996; Allison and others, 2001; Parry and others, 2007). According to the Fourth Assessment Report (AR4) of the Intergovernmental Panel on Climate Change (Parry and others, 2007), over the past 100 years (19062005) global average surface temperature has increased by $0.74^{\circ} \mathrm{C}$. Against the background of global warming, sealevel rise, water security problems, other natural disaster risks, permafrost carbon emissions and other environmental problems caused by the retreat of the cryosphere have had a serious impact on socio-economic development, arousing worldwide concern (Haeberli and Beniston, 1998; Richardson and Reynolds, 2000).

The Himalaya possess a huge snow and ice resource that constitutes an important freshwater source for countries in this region. This water resource has a high impact on the water balance and agricultural irrigation in the arid and semi-arid areas of China (Walter and others, 2010; Yao and others, 2012). Previous studies have shown that the Himalayan glaciers are retreating and thinning (Jin and others, 2005; Ren and others, 2006; Kulkarni and others, 2007; Bajracharya and Mool, 2009; Nie and others, 2010; Bolch and others, 2011, 2012; Fujita and Naimura, 2011). Due to the remote location and wide spatial distribution of these glaciers, monitoring their changes has been difficult (Frey and others, 2012; Yao and others, 2012).
The lack of sufficient numbers of in situ measurements has led to recent controversy about future Himalayan glacier change in AR4 (Parry and others, 2007). An additional problem is that mass balances of glacier resources in the Himalaya derived from in situ observation and from the Gravity Recovery and Climate Experiment (GRACE) are inconsistent or even conflicting (Fujita and Naimura, 2011; Kargel and others, 2011; Jacob and others, 2012; Yao and others, 2012). Errors also arise from the fact that researchers use different measurements and techniques to estimate glacier mass loss (Jacob and others, 2012; Gardner and others, 2013). Consequently, glacier change is perhaps more uncertain in the Himalaya than elsewhere in the world.

Many Himalayan glaciers have extensive supraglacial debris covers in their ablation zones, which impact upon both rates and spatial patterns of melting. Debris-covered areas show considerable lowering rates that vary significantly over short spatial scales and that depend on local slope and the existence of glacial lakes (Nuimura and others, 2012). Scherler and others (2011) believe that supraglacial debris cover affects the terminus dynamics and modifies glacier response to climate change. The mass loss of supraglacial debris cover occurs by melting of clean ice, glacier fragmentation, backwasting and downwasting of surface debris and calving into deep proglacial lakes (Han and others, 2006, 2010; Schomacker, 2008; Benn and others, 2012). However, a study of debris-covered glaciers in the Hindu Kush showed that thinning of debris-covered ice is not statistically different from that of clean ice (Kääb and others, 


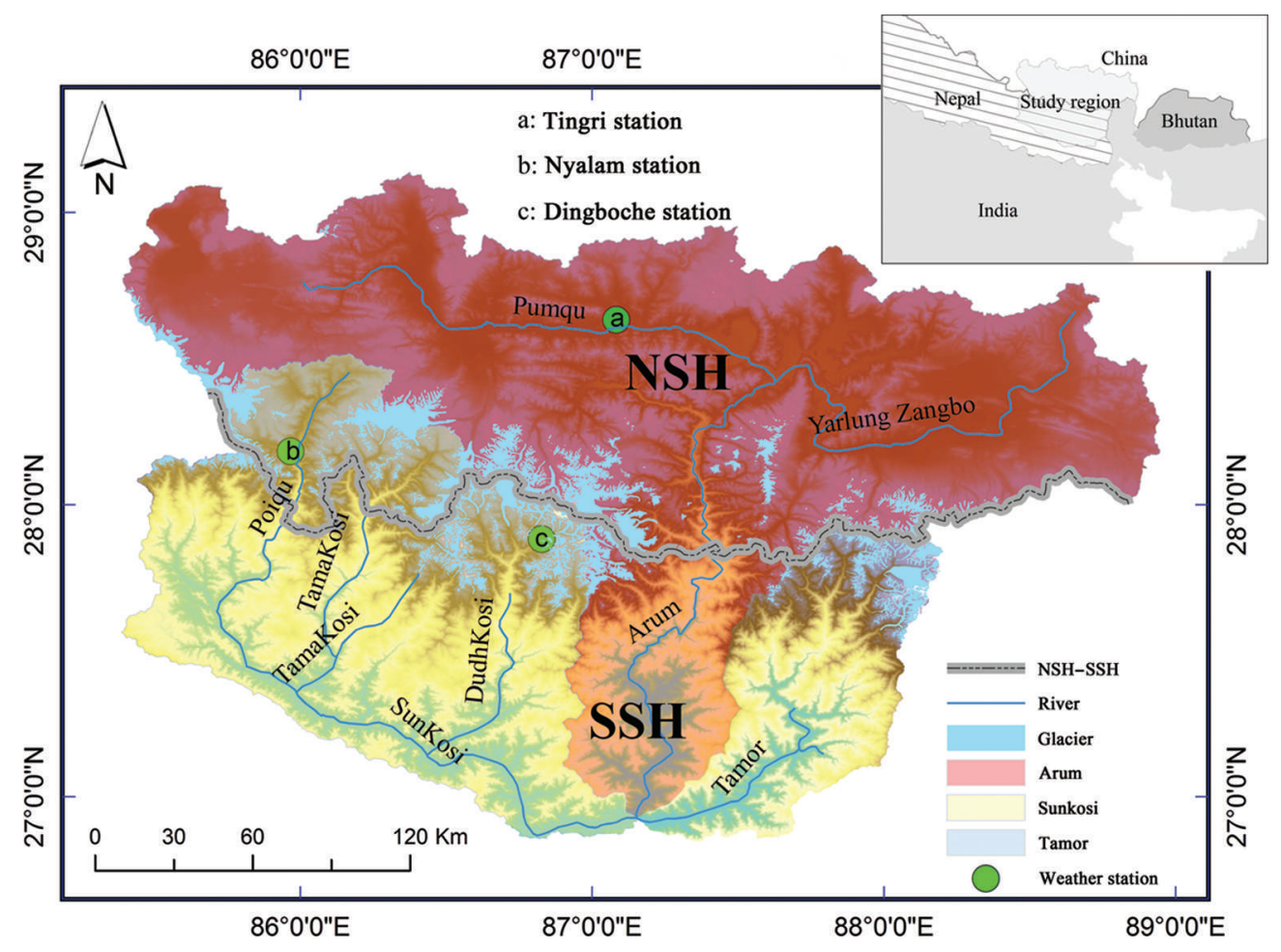

Fig. 1. Glacier distribution in the Koshi River basin (background derived from global digital elevation model (GDEM)).

2012). Glacier variation in the Himalaya will increase the risk of glacier lake outburst floods and contributes to sea-level rise (Bajracharya and Mool, 2009; Benn and others, 2012).

In this work, we use topographic maps and satellite imagery from Landsat Multispectral Scanner/Thematic Mapper/Enhanced Thematic Mapper Plus (MSS/TM/ETM+) to investigate glacier changes and document the similarities and differences between the north and south sides of Himalayan regions of the Koshi River area during 1976, 2000 and 2009/10.

\section{STUDY SITE}

Koshi River is located in southern Tibet, central Himalaya, at $26^{\circ} 47^{\prime}-29^{\circ} 12^{\prime} \mathrm{N}, 85^{\circ} 22^{\prime}-88^{\circ} 21^{\prime} \mathrm{E}$. It originates in the Himalayan region of China (north side of the Himalaya $(\mathrm{NSH})$ ) and flows into Nepal and India (south side of the Himalaya $(\mathrm{SSH})$ ). Its drainage area is $\sim 71500 \mathrm{~km}^{2}$. Of this area, $28500 \mathrm{~km}^{2}$ is located in Tibet, $31,600 \mathrm{~km}^{2}$ is located in Nepal, and $11400 \mathrm{~km}^{2}$ is located in India. Glaciers are distributed in those parts of the river basin located in China and Nepal (Fig. 1), where there are three major tributaries: Sunkosi River, Arum River (Pumqu River in China) and Tamor River. The basin areas of Sunkosi River and Arum River are 36000 and $19000 \mathrm{~km}^{2}$, respectively. Several peaks above 8000 ma.s.I. (e.g. Qomolangma (Mount Everest; $8844 \mathrm{~m})$, Cho Oyu $(8201 \mathrm{~m})$ and Lhotse $(8501 \mathrm{~m}))$ are in the catchment of the Koshi River. Large glaciers and also glacial lakes are found in the study area.

The Himalaya separate the regional climate into two distinct categories located on the north and south sides. The south side is subject to the Indian Ocean monsoon and the Pacific Ocean southeast monsoon and is thus characterized by a pronounced summer rainfall maximum and has a maritime climate. The north side is mainly affected by the Himalaya and has a typical plateau, i.e. continental, climate.
Records from two weather stations, Tingri station $\left(28.6333^{\circ} \mathrm{N}, 87.0833^{\circ} \mathrm{E}\right)$ and Nyalam station $\left(28.1833^{\circ} \mathrm{N}\right.$, $85.9667^{\circ} \mathrm{E}$ ), show that mean temperature and precipitation at these locations from 1976 to 2006 were $3.0^{\circ} \mathrm{C}$ and $286.3 \mathrm{~mm}$, and $3.8^{\circ} \mathrm{C}$ and $658.8 \mathrm{~mm}$, respectively (Fig. 1). Records from Dingboche station $\left(27.89^{\circ} \mathrm{N}, 86.83^{\circ} \mathrm{E}\right.$; 4355 ma.s.l.) on SSH show an annual average temperature of $-0.3^{\circ} \mathrm{C}$ and an annual average precipitation of $\sim 500 \mathrm{~mm}$ during the 1988-2008 period (Rajchal, 2006; Salerno and others, 2008; Wang, 2013). The elevation difference leads to decreasing precipitation as altitude increases. For example, the annual average precipitation at Namche Bazar station $\left(27.83^{\circ} \mathrm{N}, 86.72^{\circ} \mathrm{E} ; 3450 \mathrm{~m}\right.$ a.s.l. $)$ on $\mathrm{SSH}$ is $\sim 1000 \mathrm{~mm}$, which is more than at Dingboche station. The precipitation on $\mathrm{SSH}$ is more than on $\mathrm{NSH}$, leading to a lower snowline on $\mathrm{SSH}(5500 \mathrm{~m})$ than on NSH $(6000 \mathrm{~m})$.

\section{DATA AND METHODS}

\section{Topographic maps and remote-sensing images}

Our study uses 39 topographic maps at scales of $1: 50000$ and 1:100000. These maps were derived from aerial photographs acquired between 1971 and 1980 by the Chinese military geodetic service. They were scanned, georeferenced and rectified with a kilometer grid. The map coordinates were expressed using the Albers conic equalarea projection. Glacier outlines, digitized using ArcMap software, formed the basic reference data for changes in the Koshi River glaciers. Glaciers in Nepal are documented in the Nepal glacier inventory (Mool and others, 2001), derived from topographic maps of India and Nepal between the 1960s and 1980s. However, the period covered by the topographic maps is almost 20 years, rather than the short period of a few years that would allow glacier reference data of nearly the same time to be produced; in addition, the 
Table 1. Overview of the satellite image data sources applied

\begin{tabular}{|c|c|c|c|}
\hline Satellite & Path, row & Image resolution & Acquisition date \\
\hline \multirow[t]{4}{*}{ Landsat MSS } & $150 r 40$ & 57 & 19 Dec 1976 \\
\hline & $150 r 41$ & 57 & 19 Dec 1976 \\
\hline & $151 r 40$ & 57 & 7 Jan 1977 \\
\hline & $151 \mathrm{r} 41$ & 57 & 20 Dec 1976 \\
\hline \multirow[t]{5}{*}{ Landsat 5 TM } & $139 r 40$ & 30 & 9 Nov 2009 \\
\hline & $139 r 41$ & 30 & 9 Nov 2009 \\
\hline & $140 r 40$ & 30 & 31 Oct 2009 \\
\hline & $140 \mathrm{r} 41$ & 30 & 10 Jan 2010 \\
\hline & $141 \mathrm{r} 40$ & 30 & 7 Nov 2009 \\
\hline \multirow[t]{6}{*}{ Landsat ETM+ } & $139 r 40$ & 15 & 8 Nov 2000 \\
\hline & $139 r 41$ & 15 & 26 Dec 2000 \\
\hline & $140 r 41$ & 15 & 30 Oct 2000 \\
\hline & $141 \mathrm{r} 40$ & 15 & 22 Nov 2000 \\
\hline & $141 \mathrm{r} 41$ & 15 & 27 Dec 2001 \\
\hline & $140 \mathrm{r} 40$ & 15 & 30 Oct 2000 \\
\hline \multirow{5}{*}{$\begin{array}{l}\text { Landsat } 7 \mathrm{TM}+\text {, } \\
\text { SCL OFF }\end{array}$} & $139 r 40$ & 15 & 16 Oct 2009 \\
\hline & $139 r 41$ & 15 & 10 Feb 2009 \\
\hline & $140 r 40$ & 15 & 23 Oct 2009 \\
\hline & $140 r 41$ & 15 & 8 Nov 2009 \\
\hline & $141 \mathrm{r} 40$ & 15 & 30 Oct 2009 \\
\hline
\end{tabular}

topographic maps information was missed. Our study also uses four Landsat MSS images acquired in 1976 and 1977 which cover a period of $<1$ month (Table 1), to generate a reference inventory of glaciers in Nepal that fall within the Koshi River basin by manual delineation.

We also use six Landsat ETM+ scenes with $15 \mathrm{~m}$ resolution acquired in 2000, and Landsat TM data with $30 \mathrm{~m}$ resolution acquired in 2009/10, to monitor glacier extent in 2000 and 2009/10. Unfortunately, it was difficult to select available images in 2009/10 due to the snow cover in Koshi River, especially on $\mathrm{SSH}$. Therefore, our study uses several Landsat ETM+ scan-line corrector off (SLC OFF) data with $15 \mathrm{~m}$ resolution, acquired in 2009 (Table 1), as supplementary data to check the glacier extent covered by snow in 2009. This work will help reduce the glacier extent errors caused by snow. Landsat images are provided by the US Geological Survey (USGS; http://glovis.usgs.gov) and the Global Land Cover Facility. The image data were orthorectified or rectified using the Universal Transverse Mercator (UTM) coordinate system referenced to the World Geodetic System 1984 ellipsoidal elevation (WGS84). All images were subsequently reprojected in the Albers conic equal-area projection to be consistent with the topographic maps described previously.

Currently, different criteria can be used to extract glacier boundaries from satellite images, such as those based on spectral ratio (band4/band5, band3/band5, normalizeddifference snow index (NDSI)), supervised classification and unsupervised classification (Li and others, 1998; Paul and others, 2000, 2002; Zhang and others, 2001). Furthermore, Advanced Spaceborne Thermal Emission and Reflection Radiometer (ASTER) imagery combined with digital elevation model (DEM) and thermal infrared ASTER imagery can be used to delineate glacier debris-cover extent semiautomatically (Paul and others, 2004; Shukla and others, 2010). Although the delineation methods were applied as accurately as possible, it is still difficult to detect glacier outlines correctly due to debris cover and snow cover. Consequently, manual digitizing of glacier extents was used for the multispectral images (MSS in 1976, Landsat ETM in 2000 and Landsat5 TM/Landsat7 ETM) in 2009/10.

\section{Meteorological data}

Meteorological data in China are obtained from the China Meteorological Data Sharing Service System (http:// cdc.cma.gov.cn/home.do). Two weather stations (Tingri and Nyalam) were used to analyze climate changes during 1972-2010. Meteorological data in Nepal are provided by the International Centre for Integrated Mountain Development (ICIMOD; Rajchal, 2006). They span the period 19882008; some years have data missing.

\section{Precision evaluation}

Our study uses different spatial and temporal resolution data sources (Table 1). Hence, it is necessary to assess the uncertainty of the results to ascertain the accuracy. Numerous factors affect the certainty of glacier delineation in mountain regions (e.g. clouds and snow cover; the sensor's spatial resolution; spectral characteristics; mountain shadows; mixed-pixel problems; image-processing problems; and disagreements between manually and automatically derived outlines). Glacier mapping uncertainty depends mainly on the spatial and radiometric resolution of the image sources and the conditions at the time of acquisition (Bhambri and others, 2013); less than half-pixel accuracy is usually achieved (Bolch and others, 2010).

The analyst's misinterpretation of glacier imagery also leads to inaccuracy, though guidelines were developed within the framework of the Global Land Ice Measurements from Space (GLIMS) initiative (Raup and Khalsa, 2007). For example, lateral moraine and end moraine should not be included as part of the glacier, while debris-covered ice should be included, but neither of these conventions is followed (Nie and others, 2010). However, assessment of the uncertainty is difficult because images are not usually acquired at the same time or with the same spatial resolution (Paul and others, 2013).

Previous experience suggests that debris cover and spatial resolution are two key causes of uncertainty (Williams and others, 1997; Silverio and Jaquet, 2005; Paul and others, 2013). The uncertainty associated with resolution concentrates on the edge of the glacier and the region of intersection between rock and glacier, so it is evaluated by analyzing the glacier's edge pixels (Wang, 2013). We used a buffer area with half the sensor resolution to calculate the uncertainty in the software package ArcMap. The results show that the higher the sensor resolutions, the smaller the uncertainty. The glacier outlines derived from Landsat ETM+ in 2000 thus have a smaller uncertainty than those derived from Landsat MSS in 1976 and Landsat TM in 2009. Furthermore, the larger the glacier, the smaller the uncertainty. Glaciers less than $1 \mathrm{~km}^{2}$ typically have an uncertainty larger than $8.2 \%$; the maximum uncertainty is $33 \%$, derived from Landsat MSS. The uncertainty associated with our analysis is shown in Table 2.

Standard uncertainty propagation was used to calculate the overall uncertainty during 1976-2009:

$$
\delta=\sqrt{\sum_{i=1}^{n} \delta_{i}^{2}}
$$

where $\delta$ is the overall uncertainty in this study and $\delta_{i}$ is the uncertainty component at different times

The uncertainties estimated for the time periods 19762000, 2000-09 and 1976-2009 are 5.1\%, 3.1\% and 5.6\%, respectively. The overall uncertainty in 1976, 2000 and 2009 is $5.8 \%$. 


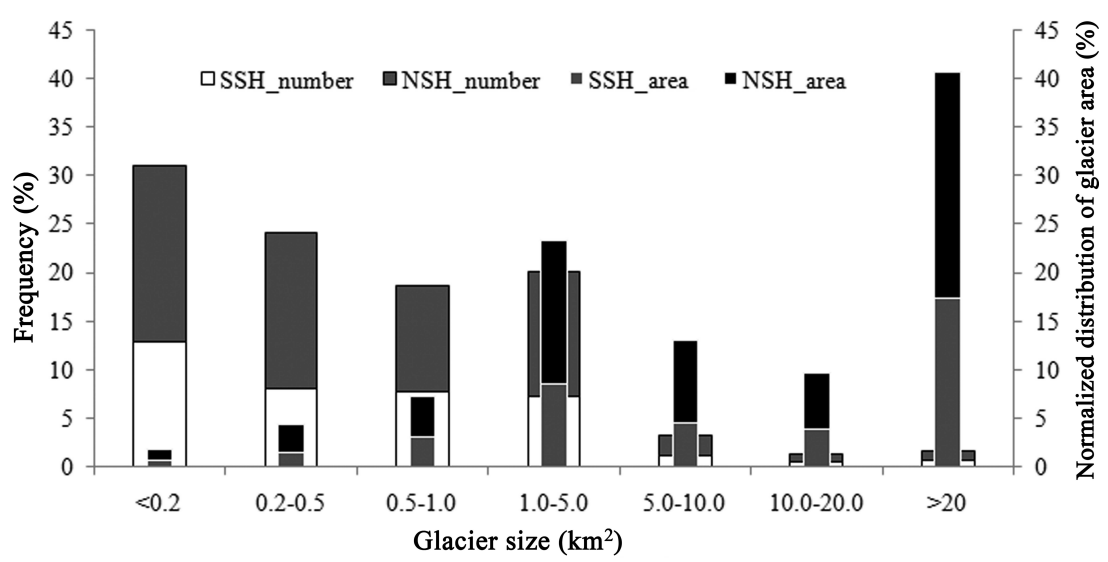

Fig. 2. The normalized frequency distribution of glaciers and the normalized distribution of their areas in the seven glacier area-size classes on $\mathrm{SSH}$ and $\mathrm{NSH}$.

\section{RESULTS}

\section{Inventory of glaciers in the Koshi River catchment}

Our analysis shows that there were 2061 glaciers with a total area of $3225 \pm 90.3 \mathrm{~km}^{2}$ in the Koshi River catchment area in 2009 (Fig. 1). About 1282 of these glaciers (55.1\% of the total number) are $<0.5 \mathrm{~km}^{2}$ in area, and these small glaciers make up $6.2 \%$ of the total glacier area. About 442 glaciers (20.1\% of the total number) are in the area range $1-5 \mathrm{~km}^{2}$, and these make up $23.3 \%$ of the total glacier area. There are 29 glaciers $\left(1.6 \%\right.$ of the total number) in the $>20 \mathrm{~km}^{2}$ area class and these make up $40.6 \%$ of the total glacier area. Thus, although small glaciers are more numerous than large glaciers, a high proportion of the glacier area is constituted by the few large glaciers.

Figure 2 depicts the distribution of glacier population and area in different area-size classes normalized to the total number and area in the study region. The glacier number and area are larger on NSH than on $\mathrm{SSH}$. There are 1290 glaciers on $\mathrm{NSH}$, accounting for $61.7 \%$ of the total number of glaciers in the Koshi River catchment, with an area of $1961.0 \pm 54.90 \mathrm{~km}^{2}$, accounting for $60.4 \%$ of the total glacier area; and 771 glaciers on $\mathrm{SSH}$, accounting for $38.3 \%$ of the total number of glaciers, with an area of $1264.1 \pm 35.4 \mathrm{~km}^{2}$, accounting for $39.6 \%$ of the total glacier area. The mean glacier sizes on NSH and SSH are 1.52 and $1.64 \mathrm{~km}^{2}$, respectively.

\section{Glacier area change}

Comparison of the total area of all glaciers in the Koshi River basin in 1976 with their total area in 2000 and 2009 (Table 3 ) reveals a reduction by $\sim 775.4 \pm 224.0 \mathrm{~km}^{2}$, or
$19.4 \pm 5.6 \%\left(0.59 \pm 0.17 \% \mathrm{a}^{-1}\right)$. The number of glaciers also decreased, by 145, during the period 1976-2009. The mean size of glaciers in the study area decreased from $1.81 \mathrm{~km}^{2}$ to $1.56 \mathrm{~km}^{2}$. During the sub-period 1976-2000, total glacier area reduced by about $641.7 \pm 204.0 \mathrm{~km}^{2}$, or $16.0 \pm 5.1 \%$, with a mean rate of glacier area loss of $0.67 \pm 0.21 \% \mathrm{a}^{-1}$. During 2000-09, the glacier area decreased about $133.7 \pm 107.5 \mathrm{~km}^{2}$, or $4.0 \pm 3.2 \%$, with a mean rate of $0.44 \pm 0.36 \% \mathrm{a}^{-1}$. This suggests that the rate of glacier shrinkage has slowed.

Comparison of glacier changes on $\mathrm{SSH}$ and $\mathrm{NSH}$ shows that their total glacier areas shrank by about $321.3 \pm 88.8 \mathrm{~km}^{2}$ and $454.2 \pm 135.3 \mathrm{~km}^{2}$, respectively, or $20.3 \pm 5.6 \% \quad\left(0.62 \pm 0.17 \% \mathrm{a}^{-1}\right)$ and $18.8 \pm 5.6 \%$ $\left(0.57 \pm 0.17 \% \mathrm{a} \mathrm{a}^{-1}\right)$, respectively, during 1976-2009. During 1976-2000, glaciers on SSH and NSH shrank about $238.1 \pm 80.9 \mathrm{~km}^{2}$ and $403.6 \pm 123.2 \mathrm{~km}^{2}$, or $15.0 \pm 5.1 \%$ $\left(0.62 \pm 0.21 \% \mathrm{a}^{-1}\right)$ and $16.7 \pm 5.1 \%\left(0.70 \pm 0.21 \% \mathrm{a}^{-1}\right)$, respectively. There are some differences in glacier change rate during 2000-09. Over this period, glacier area on SSH decreased by $6.2 \pm 3.2 \%\left(0.68 \pm 0.36 \% \mathrm{a}^{-1}\right)$ while glacier area on $\mathrm{NSH}$ decreased by $2.5 \pm 3.2 \%\left(0.27 \pm 0.36 \% \mathrm{a}^{-1}\right)$. Consequently, glaciers on $\mathrm{SSH}$ retreated faster than those on $\mathrm{NSH}$. The number of glaciers on $\mathrm{SSH}$ increased by about 8 , but the number of glaciers on NSH decreased by 27 .

Since glaciers with size $<1 \mathrm{~km}^{2}$ have a smaller total area and larger uncertainty in area (Table 2), we performed the glacier-area change analysis again, with their changes excluded. We found that the maximum contribution to glacier area loss comes from those glaciers within the area range $1-5 \mathrm{~km}^{2}$, which contributed $32.0 \%$ of total area loss between 1976 and 2009; the second largest contribution

Table 2. Uncertainty of glacier area according to glacier area classification

\begin{tabular}{|c|c|c|c|c|c|c|c|c|}
\hline \multirow[t]{3}{*}{ Year } & \multicolumn{7}{|c|}{ Glacier area size $\left(\mathrm{km}^{2}\right)$} & \multirow{3}{*}{$\begin{array}{c}\text { Sum } \\
\%\end{array}$} \\
\hline & $<0.2$ & $0.2-0.5$ & $0.5-1$ & $1.0-5.0$ & $5.0-10.0$ & 10.0-20.0 & $>20.0$ & \\
\hline & $\%$ & $\%$ & $\%$ & $\%$ & $\%$ & $\%$ & $\%$ & \\
\hline 1976 & 33.0 & 19.5 & 13.5 & 12.7 & 6.2 & 4.8 & 3.4 & 4.9 \\
\hline 2000 & 16.7 & 12.2 & 8.1 & 6.3 & 3.1 & 2.4 & 1.7 & 2.8 \\
\hline
\end{tabular}




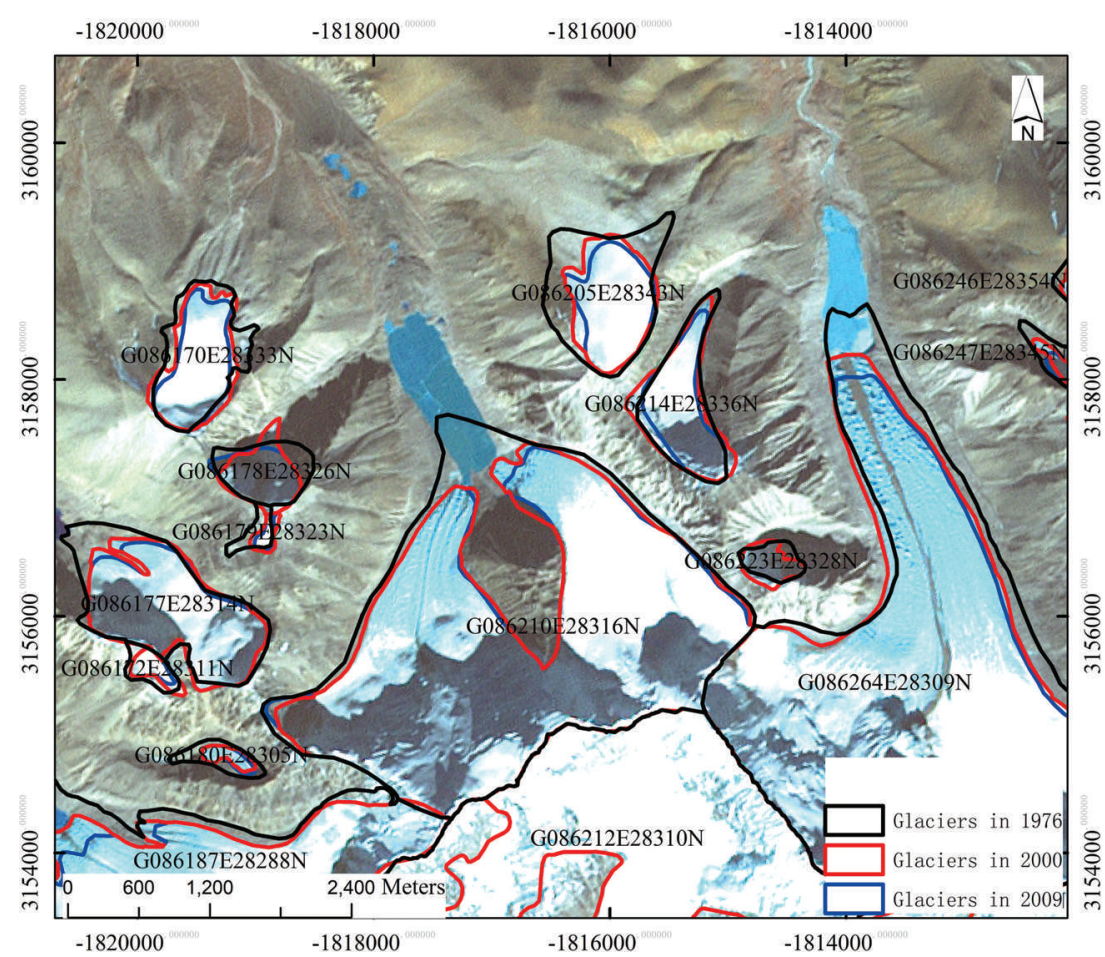

Fig. 3. Changes of example glaciers during 1976-2009 (background: Landsat ETM+ acquired in 2000, path 141, row 40). Black line: glacier outlines in 1976; red line: glacier outlines in 2000; blue line: glacier outlines in 2009.

comes from glaciers larger than $20 \mathrm{~km}^{2}$ which contributed $18.6 \%$. The glacier area loss between 2000 and 2009 accounts for $52 \%$ and $24 \%$ of the total area loss during the period 1976-2009 on SSH and NSH, respectively. Glaciers larger than $5 \mathrm{~km}^{2}$ account for $27.0 \%$ of the area loss on $\mathrm{SSH}$. We observed that most debris-covered glacier tongues larger than $10 \mathrm{~km}^{2}$ on SSH do not retreat as much as other glaciers because the debris keeps them stagnant or limits their recession. Nevertheless, glaciers on $\mathrm{SSH}$ retreat at a higher rate $\left(0.68 \pm 0.36 \% \mathrm{a}^{-1}\right)$ from 2000 to 2009 because mass loss is focused in the clean ice or middle parts of glacier ablation zones.

One glacier (No. G086210E28316N), with an area of $7.44 \mathrm{~km}^{2}$ in 1976, was divided into two glaciers in 2000 , which had areas of 3.26 and $2.80 \mathrm{~km}^{2}$ respectively, a total area loss of $18.5 \%$. Both glaciers continued to shrink, yielding a decrease in area of $0.1 \mathrm{~km}^{2}$, or $1.7 \%$, between 2000 and 2009. The glacier with an area of $3.26 \mathrm{~km}^{2}$ was almost instable. Another glacier (G086264E28309N) which was close to glacier No. G086210E28316N also underwent shrinkage. While both glaciers G086210E28316N and G086264E28309N retreated from 1976 to 2009, the glacier moraine lakes expanded where they were parts of both glaciers in 1976 (Fig. 3).

\section{DISCUSSION AND CONCLUSION}

\section{Glacier changes in surrounding areas}

Glacier retreat has been reported for many parts of the Hindu Kush-Himalaya against the background of worldwide warming (Fujita and Naimura, 2011; Bolch and others, 2012; Frey and others, 2012). However, these previous studies did not consider a whole basin nor did they offer a comparison between SSH and NSH. Our results establish that the loss of glacier area in the Koshi River catchment $\left(0.59 \pm 0.17 \% \mathrm{a}^{-1}\right)$ is one of the fastest reported in the Himalaya during 1976-2009. For example, existing studies derived from 466 glaciers in Chenab, Parbati and Baspa basins, East Himalaya, show that glacier area reduced from

Table 3. Glacier changes in Koshi during 1976-2009

\begin{tabular}{|c|c|c|c|c|c|c|c|c|c|}
\hline \multirow[t]{3}{*}{ Year } & \multicolumn{3}{|c|}{$\mathrm{SSH}$} & \multicolumn{3}{|c|}{$\mathrm{NSH}$} & \multicolumn{3}{|c|}{ Koshi } \\
\hline & \multirow[t]{2}{*}{ Number } & Area & $\begin{array}{c}\text { Glacier area } \\
\text { change }\end{array}$ & Number & Area & $\begin{array}{c}\text { Glacier area } \\
\text { change }\end{array}$ & Number & Area & $\begin{array}{c}\text { Glacier area } \\
\text { change }\end{array}$ \\
\hline & & $\mathrm{km}^{2}$ & $\%$ & & $\mathrm{~km}^{2}$ & $\%$ & & $\mathrm{~km}^{2}$ & $\%$ \\
\hline 1976 & 846 & $1585.4 \pm 77.7$ & - & 1360 & $2415.2 \pm 118.4$ & - & 2206 & $4000.5 \pm 196.0$ & - \\
\hline 2009 & 771 & $1264.1 \pm 35.4$ & $-6.2 \pm 3.2$ & 1290 & $1961.0 \pm 54.9$ & $-2.5 \pm 3.2$ & 2061 & $3225.1 \pm 90.3$ & $-4.0 \pm 3.2$ \\
\hline 1976-2009 & & & $-20.3 \pm 5.6$ & & & $-18.8 \pm 5.6$ & & & $-19.4 \pm 5.6$ \\
\hline
\end{tabular}



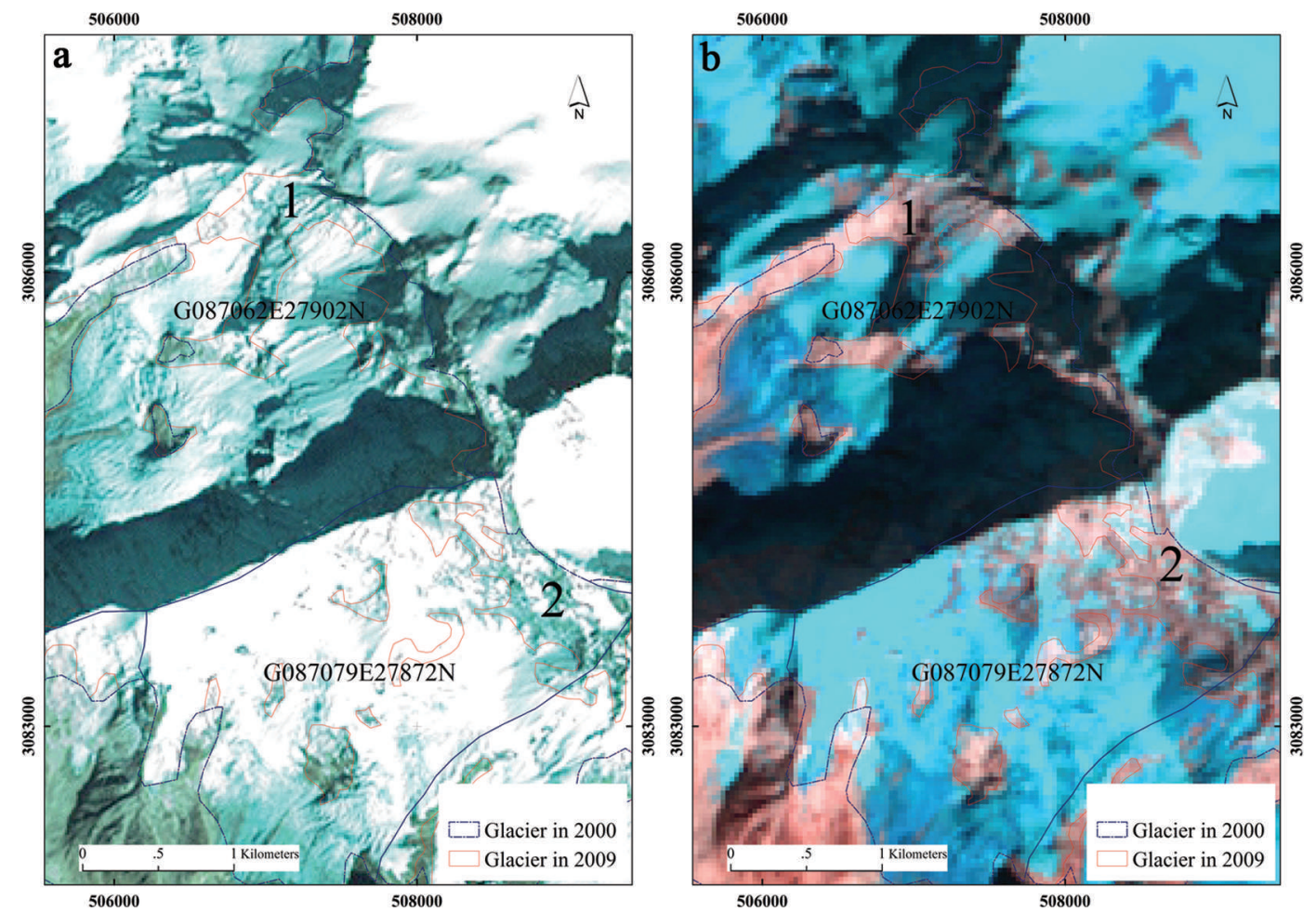

Fig. 4. An example of bedrock outcrop: (a) background: Landsat ETM+ acquired in 2000 (path 140, row 41); (b) background: Landsat TM acquired in 2009 (path 140, row 41). Both positions are bedrock outcrop covered by snow/ice in 2000.

$2077 \mathrm{~km}^{2}$ in 1962 to $1628 \mathrm{~km}^{2}$ in 2004 , accounting for $21 \%$ of total glacier area (Kulkarni and others, 2007). Glacier changes in West Himalaya were reported to be $\sim 8.4 \%$ shrinkage $\left(0.33 \% \mathrm{a}^{-1}\right)$ from 1976 to 2003 (Ye and others, 2006). Mool and others (2001) found that the area of 153 glaciers in the Poiqu River basin decreased $\sim 12.28 \mathrm{~km}^{2}$ from 1988 to 2000 , accounting for $5 \%\left(0.41 \% \mathrm{a}^{-1}\right)$ of the total area. A total of 999 glaciers in the Pumqu basin with an area of $1461.84 \mathrm{~km}^{2}$ decreased $10 \%\left(0.30 \% \mathrm{a}^{-1}\right)$ in area and $9 \%$ in number from 1970 to 2000/01 (Jin and others, 2005). Mool and others' and Jin and others' results reflected only part of the glacier change in the Koshi River basin. Similar work was done in the Qomolangma region, where the glacier recession was $0.30 \% \mathrm{a}^{-1}$ during $1974-2008$, with slower glacier retreat since 2000 (Ye and others, 2009). Nie and others (2010) surveyed glacier changes in the Qomolangma nature reserve where glacier area decreased $502 \pm 0.04 \mathrm{~km}^{2}$, or $15.6 \%$, during 1976-2006. However, this result cannot be compared with our glacier change estimates for the Koshi basin, since these authors excluded potentially debris-covered regions from their glacier mapping.

\section{Bedrock outcrop}

Glacier recession usually occurs in the glacier tongue and glacier lateral where the end moraine and lateral moraine are formed. We also noted that glacier shrinkage occurs in a few parts of the accumulation region on SSH (Fig. 4). Due to steep terrain, conditions for ice development here are poor. These regions were sometimes snow-covered or had a small ice depth. However, the ice dies easily away and there is bedrock outcrop. This is part of the glacier accumulation region and bears the ice redistribution. In this work, we also consider the bedrock outcrop as glacier shrinkage. This is one reason why the glacier change is larger on $\mathrm{SSH}$ than on NSH from 2000 to 2009.

\section{Reasons for glacier variation}

Glacier variation is a complex response to climate change mediated by a time lag which is affected by several factors (e.g. glacier size, glacier bed slope, glacier type). The quantitative relationship between glacier shrinkage and climate change is difficult to pin down. Tingri station, located on the highest-elevation site on NSH and close to the region where glaciers are distributed, provides a relevant climatic record for our study area. A warming trend in this station's temperature record during 1972-2011 can be seen in Figure 5 . Temperature has risen by $1.5^{\circ} \mathrm{C}$ in the past 39 years, with a sharp rise around 1997 . Winter temperature has increased significantly (Yang and others, 2011).

The Tingri station precipitation record showed a slight increase during 1972-2011. There were dry years between 1980 and 1998 (Fig. 5). A separate record derived from ice cores located in the region indicates that precipitation decreased rapidly from the 1950s to the 1960s, then kept relatively steady, and decreased between 1980 and 1997 (Ren and others, 2004). Precipitation has increased again since 1997. Temperature increase generally increases glacier ablation rates, and reduced precipitation before 1997 led to less net ice accumulation in this period. The warming trend on SSH is consistent with NSH (Wang, 2013). Thus, we believe that glacier retreat during 1976-2000 can be attributed primarily to air-temperature increase and precipitation decrease. We further suggest that glacier retreat during 2000-09 was controlled by temperature increase, even though precipitation increased at the same time; the increased accumulation could not offset ice losses to surface melting driven by higher temperature.

In this study, we have presented a new glacier inventory for the whole Koshi River basin derived from data sources including multispectral satellite imagery. The new inventory indicates that there were 2061 glaciers with an area of 

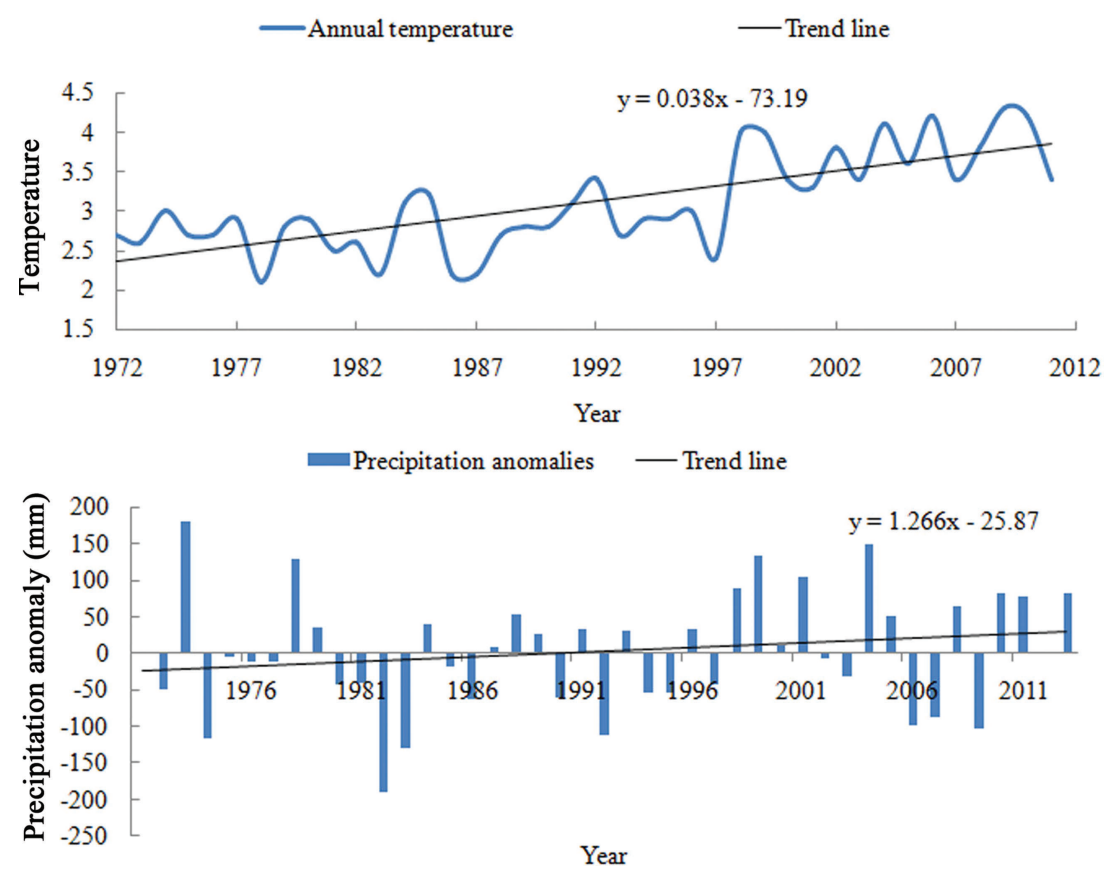

Fig. 5. Changes in mean air temperature and precipitation during 1972-2011 recorded at Tingri station.

$3225.1 \pm 90.3 \mathrm{~km}^{2}$ in 2009. Comparison with serial glacier mapping derived from different data sources reveals that the glacier area in Koshi River basin shrank by $19.4 \pm 5.6 \%$ $\left(0.59 \pm 0.17 \% \mathrm{a}^{-1}\right)$ during $1976-2009$. The number of glaciers has decreased from 2206 to 2061. Several glaciers $\left(<1 \mathrm{~km}^{2}\right)$ have vanished and a couple of glaciers were dismembered and divided into two or more individual glaciers during 1976-2009 (e.g G086210E28316N and G086264E28309N in Fig. 3). Glacier reduction was slightly faster on $\mathrm{SSH}(20.3 \pm 5.6 \%)$ than on $\mathrm{NSH}(18.8 \pm 5.6 \%)$ from 1976 to 2009, and especially from 2000 to 2009.

\section{ACKNOWLEDGEMENTS}

We thank Felix Ng and Doug MacAyeal for careful reviews and helpful suggestions. This work was supported by the external Cooperation Program of the Chinese Academy of Sciences (grant GJHZ0954), the National Natural Science Foundation of China (grants 41030527 and 41071047), and the Ministry of Science and Technology of the People's Republic of China (grant 2010CB951401). It was also funded by the China Scholarship Council and State Key Laboratory of Cryospheric Sciences (SKLCS-ZZ-2012-0002). ASTER GDEM is a product of METI (Ministry of Economy, Trade and Industry, Japan) and NASA. Landsat images come from USGS (http://glovis.usgs.gov) and the Global Land Cover Facility.

\section{REFERENCES}

Allison I, Barry RG and Goodison B eds. (2001) Climate and cryosphere (CLiC) project. Science and Co-ordination Plan, Version 1. (WCRP-114/WMO/TD No. 1053) World Climate Research Programme/World Meteorological Organization, Geneva

Bajracharya SR and Mool P (2009) Glaciers, glacial lakes and glacial lake outburst floods in the Mount Everest region, Nepal. Ann. Glaciol., 50(53), 81-85

Benn DI and 9 others (2012) Response of debris-covered glaciers in the Mount Everest region to recent warming, and implications for outburst flood hazards. Earth-Sci. Rev., 114(1-2), 156-174 (doi: 10.1016/j.earscirev.2012.03.008)

Bhambri R, Bolch T, Kawishwar P, Dobhal DP, Srivastrava D and Pratap B (2013) Heterogeneity in glacier response in the upper Shyok valley, northeast Karakoram. Cryosphere, 7(4), 1385-1398 (doi: 10.5194/tc-7-1385-2013)

Bolch T and 7 others (2010) A glacier inventory for the western Nyainqentanglha Range and Nam Co Basin, Tibet, and glacier changes 1976-2009. Cryosphere, 4(2), 429-467

Bolch T, Pieczonka T and Benn DI (2011) Multi-decadal mass loss of glaciers in the Everest area (Nepal Himalaya) derived from stereo imagery. Cryosphere, 5(2), 349-358 (doi: 10.5194/tc-5349-2011)

Bolch T and 10 others (2012) The state and fate of Himalayan glaciers. Science, 336(6079), 310-314 (doi: 10.1126/science. 1215828)

Cheng G (1996) The role of cryosphere in climate change. In G. Cheng ed. Proceedings of the 5th Chinese Conference on Glaciology and Geocryology, 18-22 August 1996, Lanzhou, China. Gansu Culture Press, Lanzhou, 807-817 [in Chinese with English summary]

Frey H, Paul F and Strozzi T (2012) Compilation of a glacier inventory for the western Himalayas from satellite data: methods, challenges and results. Remote Sens. Environ., 124, 832-843 (doi: 10.1016/j.rse.2012.06.020)

Fujita K and Nuimura T (2011) Spatially heterogeneous wastage of Himalayan glaciers. Proc. Natl Acad. Sci. USA (PNAS), 108(34), 14011-14 014 (doi: 10.1073/pnas.1106242108)

Gardner AS and 15 others (2013) A reconciled estimate of glacier contributions to sea level rise: 2003 to 2009. Science, 340(6134), 852-857 (doi: 10.1126/science.1234532)

Haeberli W and Beniston M (1998) Climate change and its impacts on glaciers and permafrost in the Alps. Ambio, 27(4), 258-265

Han H, Ding Y and Liu S (2006) A simple model to estimate ice ablation under a thick debris layer. J. Glaciol., 52(179), 528-536 (doi: 10.3189/172756506781828395)

Han H, Wang J, Wei J and Liu S (2010) Backwasting rate on debriscovered Koxkar glacier, Tuomuer mountain, China. J. Glaciol., 56(196), 287-296 (doi: 10.3189/002214310791968430)

Jacob T, Wahr J, Pfeffer WT and Swenson S (2012) Recent contributions of glaciers and ice caps to sea level rise. Nature, 482(7386), 514-518 
Jin R, Xin L, Che T, Wu L and Mool P (2005) Glacier area changes in the Pumqu river basin, Tibetan Plateau, between the 1970s and 2001. J. Glaciol., 51(175), 607-610 (doi: 10.3189/ 172756505781829061)

Kääb A, Berthier E, Nuth C, Gardelle J and Arnaud Y (2012) Contrasting patterns of early twenty-first-century glacier mass change in the Himalayas. Nature, 488(7412), 495-498 (doi: 10.1038/nature11324)

Kargel JS, Cogley JG, Leonard GJ, Haritashya U and Byers A (2011) Himalayan glaciers: the big picture is a montage. Proc. Natl Acad. Sci. USA (PNAS), 108(36), 14 709-14 710

Kulkarni AV and 6 others (2007) Glacial retreat in Himalaya using Indian remote sensing satellite data. Curr. Sci., 92(1), 69-75

Li Z, Sun W and Zeng Q (1998) Measurement of glacier variation in the Tibetan Plateau using Landsat data. Remote Sens. Environ., 63(3), 258-264 (doi: 10.1016/S0034-4257(97)00140-5)

Mool PK, Bajracharya SR and Joshi SP (2001) Inventory of glaciers, glacial lakes and glacial lake outburst floods: monitoring and early warning systems in the Hindu Kush-Himalayan region, Nepal. International Centre for Integrated Mountain Development with United Nations Environment Programme/Regional Resource Centre for Asia and the Pacific, Kathmandu

Nie Y, Zhang Y, Liu L and Zhang J (2010) Monitor glacier change based on remote sensing in the Mt. Qomolangma National Nature Preserve, 1976-2006. Acta Geogr. Sin., 65(1), 13-28 [in Chinese with English summary]

Nuimura T, Fujita K, Yamaguchi S and Sharma RR (2012) Elevation changes of glaciers revealed by multitemporal digital elevation models calibrated by GPS survey in the Khumbu region, Nepal Himalayas, 1992-2008. J. Glaciol., 58(210), 648-656 (doi: 10.3189/2012JoG11J061)

Parry ML, Canziani OF, Palutikof JP, Van der Linden PJ and Hanson CE (2007) Climate change 2007: impacts, adaptation and vulnerability. Contribution of Working Group II to the Fourth Assessment Report of the Intergovernmental Panel on Climate Change. Cambridge University Press, Cambridge

Paul F (2000) Evaluation of different methods for glacier mapping using Landsat TM. In A Decade of Trans-European Remote Sensing Cooperation. Proceedings of the 20th EARSeL Symposium, 14-16 June 2000, Dresden, Germany. AA Balkema, Rotterdam, 239-245

Paul F, Kääb A, Maisch $M$, Kellenberger $T$ and Haeberli $W$ (2002) The new remote-sensing-derived Swiss glacier inventory: I. Methods. Ann. Glaciol., 34, 355-361 (doi: 10.3189/ 172756402781817941)

Paul F, Huggel C and Kääb A (2004) Combining satellite multispectral image data and a digital elevation model for mapping debris-covered glaciers. Remote Sens. Environ., 89(4), 510-518 (doi: 10.1016/j.rse.2003.11.007)

Paul F and 19 others (2013) On the accuracy of glacier outlines derived from remote-sensing data. Ann. Glaciol., 54(63 Pt 1), 171-182 (doi: 10.3189/2013AoG63A296)

Rajchal R (2006) Population status, distribution, management, threats and migration measures of Himalayan musk deer (Moschus chrysogaster) in Sagarmatha National Park. A report submitted to DNPWC/TRPAP, Babarmahal, Kathmandu, Nepal. Institute of Forestry, Pokhara

Raup B and Khalsa SJS (2007) GLIMS data analysis tutorial. http:// www.glims.org/MapsAndDocs/assets/GLIMS_Analysis_Tutorial_ a4.pdf
Ren J, Qin D, Kang S, Hou S, Pu J and Jing Z (2004) Glacier variations and climate warming and drying in the central Himalayas. Chinese Sci. Bull., 49(1), 65-69 (doi: 10.1007/BF02901744)

Ren J, Jing Z, Pu J and Qin X (2006) Glacier variations and climate change in the central Himalaya over the past few decades. Ann. Glaciol., 43, 218-222 (doi: 10.3189/172756406781812230)

Richardson SD and Reynolds JM (2000) An overview of glacial hazards in the Himalayas. Quat. Int., 65/66, 31-47

Salerno F, Buraschi E, Bruccoleri G, Tartari G and Smiraglia C (2008) Glacier surface-area changes in Sagarmatha national park, Nepal, in the second half of the 20th century, by comparison of historical maps. J. Glaciol., 54(187), 738-752 (doi: 10.3189/002214308786570926)

Scherler D, Bookhagen B and Strecker MR (2011) Spatially variable response of Himalayan glaciers to climate change affected by debris cover. Nature Geosci., 4(3), 156-159 (doi: 10.1038/ ngeo1068)

Schomacker A (2008) What controls dead-ice melting under different climate conditions? A discussion. Earth-Sci. Rev., 90(3-4), 103-113 (doi: 10.1016/j.earscirev.2008.08.003)

Shukla A, Arora MK and Gupta RP (2010) Synergistic approach for mapping debris-covered glaciers using optical-thermal remote sensing data with inputs from geomorphometric parameters. Remote Sens. Environ., 114(7), 1378-1387 (doi: 10.1016/ j.rse.2010.01.015)

Silverio W and Jaquet J-M (2005) Glacial cover mapping (19871996) of the Cordillera Blanca (Peru) using satellite imagery. Remote Sens. Environ., 95(3), 342-350 (doi: 10.1016/ j.rse.2004.12.012)

Walter F, O'Neel S, McNamara DE, Pfeffer T, Bassis J and Fricker HA (2010) Iceberg calving during transition from grounded to floating ice: Columbia Glacier, Alaska. Geophys. Res. Lett., 37(15), L15501 (doi: 10.1029/2010GL043201)

Wang Y (2013) Variation analysis of glaciers and glacial lakes in the past 46 years in Mt. Everest area: [D]. University of Chinese Academy of Sciences, Beijing, 27-33 [in Chinese with English summary]

Williams RS Jr, Hall DK and Chien JYL (1997) Comparison of satellite-derived with ground-based measurements of the fluctuations of the margins of Vatnajökull, Iceland, 1973-92. Ann. Glaciol., 24, 72-80

Yang X, Zhang T, Qin D, Kang S and Qin X (2011) Characteristics and changes in air temperature and glacier's response on the north slope of Mt. Qomolangma (Mt. Everest). Arct. Antarct. Alp. Res., 43(1), 147-160 (doi: 10.1657/1938-4246-43.1.147)

Yao T and 14 others (2012) Different glacier status with atmospheric circulations in Tibetan Plateau and surroundings. Nature Climate Change, 2(9), 663-667 (doi: 10.1038/nclimate1580)

Ye Q, Yao T, Kang S, Chen F and Wang J (2006) Glacier variations in the Naimona'nyi region, western Himalaya, in the last three decades. Ann. Glaciol., 43, 385-389 (doi: 10.3189/ 172756406781812032)

Ye Q, Zhong Z, Kang S, Stein A, Wei Q and Liu J (2009) Monitoring glacier and supra-glacier lakes from space in Mt. Qomolangma region of the Himalayas on the Tibetan Plateau in China. J. Mt. Sci. [China], 6, 211-220 (doi: 10.1007/s11629-009-1016-4)

Zhang, W., Z. Su and T. Li (2001) Dynamic features of glacier in the Hailuogou. In Zhong XH ed. Environment and ecosystem in the eastern edge of Qinghai-Xizang Plateau. Sichuan University Press, Chengdu, 81-101 [in Chinese with English summary] 